Int. J. Odontostomat.,

12(1):29-34, 2018.

\title{
Epidemiological Aspects of Cranioencephalic Trauma at Cuiabá Municipal Hospital, Brazil
}

\author{
Aspectos Epidemiológicos de los Traumatismos Craneoencefálicos \\ Atendidos en el Hospital Municipal de Cuiabá, Brasil
}

\begin{abstract}
Artur Cunha Vasconcelos ${ }^{1}$; Jane Capistrano Dias²; Marise Plegge Ristow Wippel²; Walbert de Andrade Vieira ${ }^{3}$; Ismário Silva de Meneses ${ }^{4}$; Maria Amália Gonzaga Ribeiro ${ }^{5}$ \& Luiz Renato Paranhos ${ }^{6}$
\end{abstract}

VASCONCELOS, A. C.; DIAS, J. C.; WIPPEL, M. P. R.; VIEIRA, W. A.; MENESES, I. S.; RIBEIRO, M. A. G. \& PARANHOS, L. R. Epidemiological aspects of cranioencephalic trauma at Cuiabá Municipal Hospital, Brazil. Int. J. Odontostomat., 12(1):2934, 2018.

ABSTRACT: Cranioencephalic trauma (CET) is defined is the combination of neural and vascular injuries and their inflammatory effects in the brain, skull and scalp. This modality of trauma may lead to motor, psychological and cognitive sequels or even death. The present study aimed to assess the main epidemiological aspects in victims of CET treated at Cuiabá Municipal Hospital (CMH), Brazil. An observational and analytical study was performed in the medical records of patients diagnosed with CET treated at CMH between July and December of 2000, 2006 and 2011. The information retrieved from the patients consisted of age, sex, place of residence, cause of trauma, association with other trauma, outcomes (death or discharge) and the severity of neurological effect (Glasgow Coma Scale). The data obtained was analyzed descriptively with absolute $(n)$ and relative (\%) quantification. Medical records of 669 victims were analyzed, out of which 567 were males (84.7\%). Male patients were aged between 20 and 39 years old (mean age: 32.8 years). The most prevalent cause of trauma was the motorcycle accident $(26.6 \%)$. The neurological severity of the CET was mild in most of the cases $(32.5 \%)$. Considering the place of residence, most of the patients ( $n=331 ; 49.5 \%)$ were from the capital city of Mato Grosso State (Cuiabá, Brazil). Four-hundred seventy-nine (71.6\%) patients progressed without death. A high prevalence rate of CET was observed at $\mathrm{CMH}$. Major attention must be given to young adult victims of motorcycle accidents.

KEY WORDS: cranioencephalic trauma, epidemiology, brain Injury.

\section{INTRODUCTION}

Cranioencephalic trauma (CET) is defined as the combination of neural and vascular injuries and their respective effects in the brain, skull and scalp (Huddleston \& Ferguson, 2006). The etiology of CET involves external physical forces that eventually result in cerebral lesions and lead to permanent or temporary functional or psychic damages. In certain circumstances patients with CET may progress with death (Farage et al., 2002; Huddleston \& Ferguson; David, 2006).

Currently, CET consists of a relevant social problem because it is often related to traffic accidents (de Moura et al., 2011; Ruy \& da Rosa, 2011). Yet the increase in traffic accidents is justified in the growing number of motorcycles and cars in large urban centers. In children and elderly CET often involves accidental falls (Silveira et al., 2011; Ramos et al., 2010) and physical aggression (de Oliveira et al., 2008). The last also figures as the main cause of CET among females (da Silva et al., 2016).

Epidemiological surveys highlight CET as a matter of public health. These studies also show that most of the patients affected are men aged in the third and fourth decades of life - which represent a significant

\footnotetext{
${ }^{1}$ Maxillofacial Surgery, Hospital and Emergency Service, Cuiabá Municipal de Hospital, Cuiabá, Mato Grosso, Brazil.

${ }^{2}$ Intensivist Physiotherapist, Intensive Care Unit, Hospital and Emergency Service, Cuiabá Municipal de Hospital, Cuiabá, Mato Grosso, Brazil.

${ }^{3}$ Undergraduation Student, Department of Dentistry, Federal University of Sergipe, Aracaju, Sergipe, Brazil.

${ }^{4} \mathrm{MSc}$ Student, Postgraduate Program in Dentistry (PRODONTO), Federal University of Sergipe, Aracaju, Sergipe, Brazil.

${ }^{5}$ Professor, Postgraduate Program in Dentistry (PRODONTO), Federal University of Sergipe, Aracaju, Sergipe, Brazil.

${ }^{6}$ Professor, Department of Preventive and Community Dentistry, School of Dentistry, Federal University of Uberlândia, Minas Gerais, Brazil.
} 
part of the society (Ramos et al.; de Moura et al.; Ruy \& da Rosa; Maia et al., 2013). The problem is even worse considering the sequels inherent to CET. It is estimated that nearly $60 \%$ of the patients with CET will progress with motor or cognitive sequels (Helmy et al., 2007). Death rates in these patients are also alarming. According to DATASUS, in 201537.306 victims died due to traffic accidents in Brazil (Ministério da Saúde, 2015).

Medical teams must be able to respond optimally to this scenario (Gentille et al., 2011). Moreover, attention must be given to the high rates of CET especially because the victims usually become highrisk patients. The present study aimed to screen the epidemiological profile of these patients in order to support public health policies in the management and prevention of CET.

\section{MATERIAL AND METHOD}

Ethical criteria. The present research was conducted after the approval of the Committee of Ethics in Research of Cuiabá University (UNIC) - protocol number: \#813.513 (CAAE: 32487114.8.0000.5165). The retrospective search performed in the archives of Cuiabá Municipal Hospital was guaranteed by the hospital director, assuring legal and ethical standards.

Type of study and sample characterization. An observational and analytical study was designed to screen the medical records of Cuiabá Municipal Hospital. Cuiabá is the capital of Mato Grosso State, in Central Brazil, with a population of nearly 585.367 inhabitants. Mato Grosso (MT) State has an estimated population of 3.305.531 inhabitants distributed in $903.202,446 \mathrm{~km}^{2}$ and 141 cities (IBGE, 2016).

The present study considered only medical records of patients diagnosed with CET treated at Cuiabá Municipal Hospital between July and December of 2000, 2006 and 2011. No restriction was applied on age and sex.

Data collection and analysis. The information registered in the medical records were retrieved using data collection forms designed specifically for the present study. These forms included age, sex, place of residence, cause of trauma, association with other trauma, outcomes (death or discharge) and the severity of neurological effect (Glasgow Coma Scale).
The date was registered in Microsoft Excel files. The data was explored with absolute (n) and relative (\%) descriptive statistics and expressed in tables.

\section{RESULTS}

The search resulted in 669 medical records, out of which 219 (32.7\%) dated from 2000; 184 (27.5 \%) from 2006 and 266 (39.8\%) from 2011.

Male patients accounted $547(84.7 \%)$ records, while females accounted $122(15.3 \%)$. The age of the sample ranged from 1 month to 91 years (mean age: $32.8 \pm 19.1)$. Considering the sample in age ranges, 190 patients $(28.4 \%)$ were aged between 0 and 19 years; 407 (60.8\%) between 20 and 59 years and $68(10.2 \%)>60$ years (Table I). The age of the patient was not reported in $0.5 \%$ of the medical records. Regarding the place of residence, 334 (49.9 $\%)$ records were registered from the city of Cuiabá, while the remaining $320(47.8 \%)$ corresponded to other cities. This information was missing in 15 records $(2.3 \%)$.

CET was more prevalent in patients involved in motorcycle accidents $(n=178 ; 26.6 \%)$, followed by those who fell $(n=151 ; 22.6 \%)$, those that got run over $(n=101 ; 15.1 \%)$, those driving into traffic accidents $(n=87 ; 13 \%)$, and those suffering aggression $(n=48 ; 7.1 \%)$. Other causes of CET included firearm injuries, contusions, bicycle accidents, accidents with domestic animals, and victims of landslides $(n=92 ; 13.8 \%)$. In 12 records the cause of CET was unclear $(1.8 \%)$.

The mean value quantified with Glasgow Coma Scale for neurological effects of CET was 11.02 $( \pm 4.05)$, ranging from 3 to 15 . More specifically, 217 (32.5\%) presented mild CET (scale scoring between 14 and 15$), 188(28.1 \%)$ presented moderate CET (between 9 and 13) and 151 (22.5\%) presented severe CET (between 3 and 8 ). The severity of CET was not registered in 113 (16.9\%) records.

Injuries associated with CET were registered in $330(49.3 \%)$ records. These injuries included: fractures (of the face, spine, tibia, femur, radius, ulna, should blade and ribs); bruises; otorrhea; lesions in the eyes, abdomen and thorax; aneurysms; other contusions; ecchymoses; amputations; and abrasions. 
VASCONCELOS, A. C.; DIAS, J. C.; WIPPEL, M. P. R.; VIEIRA, W. A.; MENESES, I. S.; RIBEIRO, M. A. G. \& PARANHOS, L. R. Epidemiological aspects of cranioencephalic trauma at Cuiabá Municipal Hospital, Brazil. Int. J. Odontostomat., 12(1):29-34, 2018.

Table I. Sample characteristics distributed between the years of sample collection.

\begin{tabular}{lcccc}
\hline \multicolumn{1}{c}{ Characteristics } & $\mathbf{2 0 0 0}(\mathbf{n})$ & $\mathbf{2 0 0 6}(\mathbf{n})$ & $\mathbf{2 0 1 1} \mathbf{( n )}$ & Total \\
\hline SEX & & & & \\
Male & 190 & 162 & 215 & $567(84.7 \%)$ \\
Female & 29 & 23 & 50 & $102(15.3 \%)$ \\
AGE & & & & \\
$0-9$ & 17 & 25 & 37 & $79(11.8 \%)$ \\
$10-19$ & 45 & 30 & 36 & $111(16.6 \%)$ \\
$20-39$ & 95 & 77 & 90 & $262(39.2 \%)$ \\
$40-59$ & 42 & 31 & 72 & $145(21.7 \%)$ \\
$>60$ & 16 & 21 & 31 & $68(10.2 \%)$ \\
n/m & 4 & 0 & 0 & $4(0.5 \%)$ \\
Mean & $32.0 \pm 17.2$ & $31.9 \pm 19.2$ & $34.0 \pm 20.1$ & $32.8 \pm 19.1$ \\
Place of residence & & & & \\
Capital & 86 & 96 & 152 & $334(49.9 \%)$ \\
Other Cities & 127 & 84 & 109 & $320(47.8 \%)$ \\
n/m & 6 & 4 & 5 & $15(2.3 \%)$ \\
Total & $219(32.7 \%)$ & $184(27.5 \%)$ & $266(39.8 \%)$ & $669(100 \%)$ \\
\hline n: number of records; $n$ /m: not mentioned; age expressed in years & &
\end{tabular}

Most of the patients $(n=479 ; 71.5 \%)$ progressed with hospital discharge, while the remaining (142; 21.2 $\%)$ progressed with death. Forty-eight $(7.3 \%)$ patients were transferred to other hospitals.

In order to further investigate the aspects considered in the present study, comparisons between variables were performed. Table II shows the association between sex and several causes of CET.

Table II. Relation between the causes of Cranioencephalic Trauma (CET) and sex.

\begin{tabular}{lccc}
\hline \multicolumn{1}{c}{ Cause of CET } & \multicolumn{3}{c}{ Sex } \\
Males & Females & $\mathrm{n}$ \\
\hline Motorcycle accident & 160 & 18 & 178 \\
Fall & 121 & 30 & 151 \\
Run over & 71 & 30 & 101 \\
Car accident & 72 & 15 & 87 \\
Aggression & 43 & 5 & 48 \\
Other & 84 & 8 & 92 \\
n/m & 12 & 0 & 12
\end{tabular}

n: number of records; $\mathrm{n} / \mathrm{m}$ : not mentioned.
Motorcycle accident was the main cause of CET among males, while in females CET was more prevalent within patients that fell or got run over.

Table III expresses the prevalence of the cause of CET in face of the different age ranges, while Table IV explores the prevalence of these injuries in different time periods. Falling was the most common cause of CET in patients aged between 0 and 9 years old $(n=31)$, between 40 and 59 years old $(n=34)$, and above 60 years old $(n=32)$. Motorcycle accidents were more prevalent in patients aged 10 and $19(n=33)$ and between 20 and $39(n=102)$ years old (Table III). Motorcycle accidents and falls were the most prevalent cause of CET in 2000, 2006 and 2011 (Table IV).

Table $V$ expresses the prevalence and severity of CET (according the Glasgow Coma Scale) in relation to the clinical prognosis. Most of the patients that progressed with death presented high severity (score between 3 and 8 ). Only 11 patients with mild severity (score between 14 and 15) progressed with death.

Table III. Prevalence of the causes of Cranioencephalic Trauma (CET) according to age range.

\begin{tabular}{|c|c|c|c|c|c|c|}
\hline \multirow[t]{2}{*}{ Cause of CET } & \multicolumn{6}{|c|}{ Age Range } \\
\hline & $0-9$ & $10-19$ & $20-39$ & $40-59$ & $>60$ & $\mathrm{n} / \mathrm{m}$ \\
\hline & $\mathrm{n}$ & $\mathrm{n}$ & $\mathrm{n}$ & $\mathrm{n}$ & $\mathrm{n}$ & $\mathrm{n}$ \\
\hline Motorcycle accident & 7 & 33 & 103 & 30 & 3 & 2 \\
\hline Fall & 29 & 9 & 34 & 46 & 32 & 1 \\
\hline Run over & 25 & 14 & 20 & 21 & 20 & 1 \\
\hline Car accident & 10 & 21 & 36 & 18 & 2 & 0 \\
\hline Aggression & 0 & 8 & 18 & 11 & 9 & 2 \\
\hline
\end{tabular}

$\mathrm{n}$ : number of records; $\mathrm{n} / \mathrm{m}$ : not mentioned; age expressed in years. 
Table IV. Prevalence of the causes of Cranioencephalic Trauma (CET) according to the year of occurrence.

\begin{tabular}{lccc}
\hline \multicolumn{1}{c}{ Cause of CET } & \multicolumn{3}{c}{ Year } \\
& 2000 & 2006 & 2011 \\
& $\mathrm{n}$ & $\mathrm{n}$ & $\mathrm{n}$ \\
\hline Motorcycle accident & 51 & 51 & 76 \\
Fall & 41 & 44 & 66 \\
Run over & 30 & 23 & 48 \\
Car accident & 41 & 23 & 23 \\
Aggression & 14 & 15 & 19 \\
\hline
\end{tabular}

$\mathrm{n}$ : number of records; $\mathrm{n} / \mathrm{m}$ : not mentioned; age expressed in years.

Table V. Relation between the severity of the lesions and the clinical prognosis.

\begin{tabular}{lccc}
\hline \multirow{2}{*}{ Glasgow } & \multicolumn{3}{c}{ Clinical Progression } \\
\cline { 2 - 4 } Coma Scale & Discharged & Transferred & Death \\
\hline Mild & 189 & 17 & 11 \\
Moderate & 152 & 12 & 24 \\
Severe & 53 & 10 & 88 \\
$\mathrm{n} / \mathrm{m}$ & 85 & 9 & 19 \\
\hline
\end{tabular}

Classification scores: Mild: 14-15; Moderate: 9-13; Severe 3-8; n/m: not mentioned.

\section{DISCUSSION}

The present research explored the data registered in medical records of Cuiabá Municipal Hospital (Cuiabá, Mato Grosso, Brazil). In the data, not only the prevalence of CET was considered but also the relation with patient's demographic data. In general, CET was more prevalent in men aged around the third and fourth decades of life victims of motorcycle accidents.

The present study corroborates the scientific literature concerning the prevalence of CET among males (Ramos et al.; Silveira et al.; de Moura et al.; Ruy \& da Rosa; dos Santos et al., 2013; Maia et al.). The difference in the prevalence of CET based on sex is possibly founded on the risk conditions to which men and women are routinely exposed (Ramos et al.). Historical and cultural aspects confirm the fact that men have a higher exposure to risks compared to women.
Similarly, CET was more prevalent among young adults. This finding confirms the scientific literature (Ramos et al.; de Moura et al.; Ruy \& da Rosa; Maia et al.) and points towards an alarming scenario. Specifically, young adults compose a large part of the active population. In practice, CET may lead to functional disabilities and hamper labor activities. Possibly, labor disability is the most important social consequence of CET.

In relation to the place of residence, it is important to note that Cuiabá Municipal Hospital is a reference center for attending CET cases in the Mato Grosso State. The present study confirmed the capacity of the hospital showing a similar distribution of patients referred from the capital $(n=331)$ and from other cities $(n=313)$. In a study performed in the city of Salvador, Brazil, the victims attended at the emergency unit were referred mostly from outside the capital (Melo et al., 2004). The present outcomes highlight the importance of having hospitals with emergency capacities for attending both patients from the capital and patients from other cities.

In accordance with previous literature, motorcycle accidents figured as the main cause behind CET (26.6 \%) (Ruy \& da Rosa; de Moura et al.). Usually, traffic accidents involve one of the following aspects: quantity of vehicles, lack of proper road infrastructure, lack of road surveillance, lack of conservation of vehicles, reckless driving and lack of punishment (Marin \& Queiroz, 2000). The number of motorcycle in Brazil increased considerably in the last decades. Consequently, related accidents also increased (National Transport Confederation, 2016). Other studies rank falls as the first cause behind CET (Ramos et al.; Maia et al.). However, in the present study, falls were ranked second among the causes of CET.

Once diagnosed with CET, the patients were examined with Glasgow Coma Scale. This neurological tool aims to assess the severity of cranial lesions through a set of simple commands and their respective responses (Bortolotti, 2012). Based on the responses, the lesions were classified into mild (score between 14 and 15), moderate (score between 9 and 13) and severe (score between 3 and 8) (Bortolotti).

In accordance with the literature (dos Santos et al.; de Moura et al.), mild lesions were more prevalent in the present study (42.3\%). Mild CET is one of the main reasons in the search for medical urgency and emergency services - not only in hospitals, but also in 
public health centers and private offices (Soares et al., 2009). The high prevalence of mild lesions is a positive outcome because it represents a smaller risk condition compared to more severe lesions. In this context, better prognosis may be expected for physical, cognitive and emotional damages (Gentille et al.).

Also following what was previously reported in the literature (Maia et al.), a large part of the sample manifested lesions other than CET. These lesions are directly related to the cause of the trauma, which is usually from strong physical impacts (Maia et al.). This information points towards the importance of having an interdisciplinary team for attending patients with $\mathrm{CET}$, especially because the secondary lesions may affect different regions in the body, such as face, limbs, ribs and organs.

The comparison between the cause of CET and sex revealed that motorcycle accidents were more prevalent in men. In women, CET was more prevalent after falling or getting run over. Most of the population that drives motorcycles consists of men. Consequently, they are more exposed to the inherent risks and accidents. These evidences are confirmed with the outcomes of the present study and the previous literature (Ruy \& da Rosa; dos Santos et al.).

Considering the causes of CET analyzed in relation to the age, the younger ( $0-9$ years) and older (40-59 and $>60$ years) patients were more affected with CET after falling. This finding shows how vulnerable these patients can be (Maia et al.). In patients aged between 10 and 39 years, motorcycle accident was the most prevalent cause. It is justified by the fact that these subjects are very active, constantly in traffic and exposed to accidents.

The analysis of Glasgow Coma Scale in relation to the clinical progression was also performed and is encouraged in the clinical practice for optimal evaluation of patients with CET. Confirming the literature, the present study observed that the more severe the CET the higher the probability of progressing to death (Saade et al., 2014).

Motorcycle accident was the most prevalent cause of CET during the years in which sampling was performed. According to the National Transport Confederation, four million motorcycles were ridden inBrazil in 2001. In 2011, this number increased to 15 million (National Transport Confederation). Along with the increase in the number of motorcycles there was an increase in the number of accidents that resulted in CET. This data highlights the need for implementing preventive and educational traffic policies to protect the population.

CONCLUSION. The present study revealed that men in the third and fourth decades of life were more affected with CET. Motorcycle accidents figured as the most prevalent cause of CET.

Despite the high number of mild lesions - that evolve with better prognosis, CET still has high morbidity rates.

Considering CET as a matter of public health, preventive and educational policies should be implemented in order to decrease the number of victims.

VASCONCELOS, A. C.; DIAS, J. C.; WIPPEL, M. P. R.; VIEIRA, W. A.; MENESES, I. S.; RIBEIRO, M. A. G. \& PARANHOS, L. R. Aspectos epidemiológicos de los traumatismos craneoencefálicos atendidos en el Hospital Municipal de Cuiabá, Brasil. Int. J. Odontostomat., 12(1):29-34, 2018.

RESUMEN: El traumatismo craneoencefálico (TCE) se define como una combinación de daño neural, insuficiencia vascular y efectos inflamatorios que comprometen el cráneo, el encéfalo y el cuero cabelludo, causando la muerte, o serias secuelas motoras, psicológicas y cognitivas. De esta forma, el objetivo de este trabajo fue evaluar los principales aspectos epidemiológicos en victimas de Traumatismo Craneoencefálico (TCE) atendidas en el Hospital y Sala de Primeros Auxilios Municipal de Cuiabá (HPSMC), Brasil. Se trata de un estudio observacional de historias clínicas del archivo del HPSMC, admitidos con diagnóstico de TCE en el período de julio a diciembre de los años 2000, 2006 y 2011. Se consideraron el rango de edad, el sexo, la procedencia de las víctimas, la causa del trauma, la asociación con otros traumas, la defunción y el alta, el cuadro neurológico (Escala de Coma de Glasgow - ECG). El análisis de los datos fue descriptivo con números absolutos y porcentajes. Se evaluaron historias clínicas de 669 víctimas de TCE, en los que el sexo masculino fue el de mayor prevalencia con 567 casos $(84,7 \%)$, con mayor incidencia en el rango de edad de 20 a 39 años $(39,2 \%)$, el promedio de edad fue de 32,8 años, siendo la etiología más frecuente los accidentes motociclísticos (26,6 \%). En el momento de la admisión de acuerdo al ECG hubo una predominancia de TCE leve (32,5\%). En cuanto a la procedencia, $331(49,5 \%)$ eran del municipio de Cuiabá. Del total de víctimas, 479 (71,6\%) evolucionaron hasta tener el alta hospitalaria. Se registró una prevalencia elevada de TCE en el HPSMC, con predominancia de víctimas adultas jóvenes de sexo masculino, siendo los accidentes motociclísticos la principal causa.

PALABRAS CLAVE: traumatismos craneoce-rebrales, epidemiología, lesiones encefálicas. 
VASCONCELOS, A. C.; DIAS, J. C.; WIPPEL, M. P. R.; VIEIRA, W. A.; MENESES, I. S.; RIBEIRO, M. A. G. \& PARANHOS, L. R. Epidemiological aspects of cranioencephalic trauma at Cuiabá Municipal Hospital, Brazil. Int. J. Odontostomat., 12(1):29-34, 2018.

\section{REFERENCES}

Bortolotti, F. Manual do ocorrista. $3^{\text {rd }}$ ed. Porto Alegre, Expansão, 2012.

da Silva, E. N.; Matos, F. R. R. O.; Pimenta, R. M. C.; Rodrigues, J. L. S. A.; Marques, J. A. M.; Musse, J. O. \& Paranhos, L. R. Epidemiological profile and characterization of oral and maxillofacial injuries in women victims of interpersonal violence. Int. J. Odontostomat., 10(1):11-6, 2016.

David, C. A. Traumatismo Cerebral. In: Jones, H. R. (Ed.). Neurologia de Netter. Porto Alegre, Artmed, 2006. pp.672-85.

de Moura, J. C.; Rangel, B. L. R.; Creôncio, S. C. E. \& Pernambuco, J. R. B. Perfil clínico-epidemiológico de traumatismo cranioencefálico do Hospital de Urgências e Traumas no município de Petrolina, estado de Pernambuco. Arq. Bras. Neurocir., 30(3):99-104, 2011.

de Oliveira, C. M. C. S.; Santos, J. S.; Brasileiro, B. F. \& Santos, T. $\mathrm{S}$. Epidemiologia dos traumatismos buco-maxilo-faciais por agressões em Aracaju/SE. Rev. Cir. Traumatol. Buco-MaxiloFac., 8(3):57-68, 2008.

dos Santos, F.; Casagranda, L. P.; Lange, C.; de Farias, J. C.; Pereira, P. M.; Jardim, V. M. R. \& Torres, A. A. P. Traumatismo Cranioencefálico: causas e perfil das vítimas atendidas no prontosocorro de Pelotas/Rio Grande do Sul, Brasil. Rev. Min. Enferm., 17(4):882-7, 2013.

Farage, L.; Colares, V. S.; Capp Neto, M.; Moraes, M. C.; Barbosa, M. C. \& Branco Junior, J. A. As medidas de segurança no trânsito e a morbimortalidade intra-hospitalar por traumatismo craniencefálico no distrito federal. Rev. Assoc. Med. Bras., 48(2):163-6, 2002.

Gentille, J. K. A.; Himuro, H. S.; Rojas, S. S. O.; Veiga, V. C.; Amaya, L. E. C. \& de Carvalho, J. C. Condutas no paciente com trauma crânioencefálico. Rev. Bras. Clin. Med. São Paulo, 9(1):74-82, 2011.

Helmy, A.; Vizcaychipi, M. \& Gupta, A. K. Traumatic brain injury: intensive care management. Br. J. Anaesth., 99(1):32-42, 2007.

Huddleston, S. S. \& Ferguson, S. G. Emergências Clínicas: Abordagens, Intervenções e Autoavaliação. Rio de Janeiro, Guanabara Koogan, 2006.

Maia, B. G.; de Paula, F. R. P.; Cotta, G. D.; Cota, M. A. L.; Públio, P. G.; Oliveira, H. \& de Oliveira, T. A. Perfil clínico-epidemiológico das ocorrências de traumatismo cranioencefálico. Rev. Neurocienc., 21(1):43-52, 2013.

Marin, L. \& Queiroz, M. S. A atualidade dos acidentes de trânsito na era da velocidade: uma visão geral. Cad. Saúde Pública, 16(1):721, 2000.

Melo, J. R. T.; da Silva, R. A. \& Moreira Jr., E. D. Características dos pacientes com trauma cranioencefálico na cidade do Salvador, Bahia, Brasil. Arq. Neuro-Psiquiatr., 62(3A):711-5, 2004.

Ministério da Saúde. Departamento de Informática do SUS (DATASUS). Informações de Saúde: Estatísticas Vitais. Brasília, Ministério da Saúde, 2015.

National Transport Confederation. Evolução da Frota de Veículos, com Placa porAno Segundo Tipo - 2002 - 2016. Brasilia, National Transport Confederation, 2016. Available from: http:// anuariodotransporte.cnt.org.br/

Ramos, E. M. S.; da Silva, M. K. B.; de Siqueira, G. R.; Vieira, R. A. G. \& França, W. L. C. Aspectos epidemiológicos dos traumatismos cranioencefálicos atendidos no Hospital Regional do Agreste de Pernambuco de 2006 a 2007. RBPS (Fortaleza), 23(1):4-10, 2010.

Ruy, E. L. \& da Rosa, M. I. Perfil epidemiológico de pacientes com traumatismo crânio encefálico. Arq. Catarin. Med., 40(3):17-20, 2011.
Saade, N.; Veiga, J. C.; Cannoni, L. F.; Haddad, L. \& Araújo, J. L. Evaluation of prognostic factors of decompressive craniectomy in the treatment of severe traumatic brain injury. Rev. Col. Bras. Cir., 41(4):256-62, 2014

Silveira, E. M.; Miranda, C. A.; Araújo, R. A. \& Enders, B. C. Perfil clínico-epidemiológico de pacientes acometidos com lesão cerebral traumática atendidos em uma unidade de emergência. Rev. Enferm. UFPE Online, 5(5):1145-50, 2011.

Soares, B. A. C.; Scatena, J. H. G. \& Galvão, N. D. Acidentes e violências na Grande Cuiabá: o que retrata a demanda dos serviços de emergência. Epidemiol. Serv. Saúde (Brasília), 18(3):265-76, 2009

Corresponding author:

Luiz Renato Paranhos

Faculdade de Odontologia

Avenida Pará, 1720 Bloco 2G, Sala 1

Umuarama

Uberlândia

Minas Gerais

BRASIL

Email: paranhos.Irp@gmail.com

Received: 20-07-2017

Accepted: 23-12-2017 